\title{
Kemampuan Guru Bahasa Indonesia Sma, Smk, Dan Ma Di Kota Mataram Dalam Merancang Rencana Pembelajaran Bahasa Indonesia Berbasis Teks
}

\author{
Susilawati $^{1)}$, Mahsun ${ }^{2)}$, Johan Mahyudi ${ }^{3)}$ \\ ${ }^{1}$ Universitas Mataram \\ Email: ${ }^{1}$ Watisusila6789@gmail.com, ${ }^{2}$ mahsunirn@gmail.com, \\ 3ohanmahyudi@unram.ac.id
}

\begin{abstract}
Abstrak. Penelitian ini bertujuan untuk mengetahui kemampuan guru bahasa Indonesiadalam mendesain rencana pelaksanaan pembelajaran teks anekdot. Penelitian ini menggunakan pendekatan kualitatif dengan metode deskriptif karena dalam penelitian ini bertujuan menggambarkan dan memaparkan isi dari objek yang akan diteliti. Sumber data penelitian adalah RPP guru kelas X Kota Mataram. Teknik pengumpulan data yang digunakan adalah simak, catat dan cakap. Hasil dari penelitian ini menunjukkan bahwa kemampuan guru kelas X Kota Mataram dalam mendesain desain rencana pelaksanaan pembelajaran (RPP) sudah dapat dikategorikan baik, sebagian besar dari rumusan instrument penilaian kesesuaian RPP pada kemampuan guru telah dapat di kuasai, namun perlu ada peningkatan pelatihan, sehingga guru tersebut dapat mengembangkan kemampuan mereka dalam mendesain dan menerapkan RPP Kurikulum 2013.
\end{abstract}

Keywords: Kemampuan Guru, Mendesain, Teks Anekdot

\section{PENDAHULUAN}

Kurikulum 2013 khusus bidang mata pelajaran bahasa Indonesia, telah mengubah paradigma pembelajaran dari yang bersifat struktural ke paradigma memandang bahasa sebagai sebuah sistem yang fungsional (sistemik fungsional) dengan unit bahasa yang menjadi basis pembelajarannya adalah teks. Halliday (dalam Mahsun: 2018) menyebutkan bahwa teks merupakan jalan menuju pemahaman tentang bahasa. Teks juga merupakan bahasa yang berfungsi atau bahasa yang sedang melaksanakan tugas tertentu dalam konteks situasi. Semua contoh bahasa hidup yang mengambil bagian tertentu dalam konteks situasi disebut teks. Dengan demikian, teks seperti dinyatakan Halliday, merupakan ungkapan pernyataan suatu kegiatan sosial yang bersifat verbal. Oleh karena itu, pembelajaran bahasa berbasis teks, selain ditujukan agar siswa dapat menggunakan bahasa sesuai konteksnya juga dapat menjadi sarana pengembangan kemampuan berpikir. Selanjutnya, perubahan kurikulum dengan paradigma pembelajaran yang turut berubah, tentu saja membawa konsekuensi berupa tuntutan penyesuaian yang fundamental dari para guru. Penyesuaian dimaksud tidak hanya menyangkut tuntutan agar guru harus benar-benar memahami substansi satuan bahasa yang akan diajarkan, yaitu teks (standar isi), tetapi juga tuntutan agar guru memahami standar kompetensi lulusan yang hendak dicapai dengan pemberian materi pembelajaran, memahami cara-cara materi itu dibelajarkan (standar proses pembelajaran), dan memahami bagaimana capaian pembelajaraan itu dievaluasi (standar proses penilaian). Untuk mengetahui sejauh mana perubahan itu dapat disiasati para guru, sehingga tujuan akhir pembelajaran bahasa Indonesia berbasis teks dapat dicapai, maka perlu dilakukan kajian penerapan kurikulum Bahasa Indonesia berbasis teks.

Berdasarkan masalah di atas penelitian ini bertujuan untuk mengetahui sejauh mana kemampuan guru bahasa Indonesia kelas $\mathrm{X}$ dalam merancang rencana persiapan pembelajaran berbasis teks di Kota Mataram. Kajian dilakukan hanya menyangkut aspek standar kompetensi lulusan yang sasaran penelitiannya adalah guru. Objek penelitian yang berupa pemahaman guru merancang rencana persiapan pembelajaran masih sangat umum 
sifatnya. Oleh karena itu perlu dijabarkan ke dalam jabaran objek yang lebih khusus, mudah diukur untuk diteliti. Dengan kata lain, komponen-komponen apa saja yang harus menjadi pusat permasalahan dalam penelitian yang menyangkut pemahaman tersebut. Patut diingat bahwa merancang persiapan pembelajaran, yang umumnya disebut Rencana Pelaksanaan Pembelajaran (RPP) sudah memiliki format standar, yang komponenkomponennya sudah relatif baku. Persoalannya, aspek apakah yang menjadi fokus pada penelitian yang mengambil objek pemahaman guru merancang RPP tersebut. Untuk keperluan itu, komponen RPP yang memerlukan elaborasi pemikiran lebih lanjutlah yang harus menjadi fokus perhatian, seperti:
a. kemampuan mengembangkan indikator dari kompetensi dasar,
b. kemampuan menentukan materi pembelajaran yang sesuai dengan indikator,

c. kemampuan menentukan metode pembelajaran dalam bentuk langkahlangkah pembelajaran untuk menyajikan materi pembelajaran, termasuk di dalamnya menentukan jumlah pertemuan untuk menuntaskan pelaksanaan pembelajaran serta media pembelajaran yang digunakan, dan

d. kemampuan menentukan bentuk evaluasi capaian hasil pembelajaran teks

\section{KAJIAN LITERATUR}

Kurikulum 2013 merupakan kurikulum berbasis kompetensi yang merupakan penyempurnaan dari Kurikulum Tingkat Satuan Pendidikan. Dalam Undang-Undang No. 20 Tahun 2003 tentang Sistem Pendidikan Nasional, pasal 1 angka 19, disebutkan bahwa kurikulum adalah seperangkat rencana dan pengaturan mengenai tujuan, isi, dan bahan pelajaran, serta cara yang digunakan sebagai pedoman penyelenggaraan kegiatan pembelajaran untuk mencapai tujuan pendidikan tertentu. Sejak zaman kemerdekaan, telah terjadi sebelas kali perubahan (penyempurnaan) kurikulum di Indonesia.

Sebagai sebuah kurikulum yang berbasis kompetensi, elemen pertama yang disempurnakan dalam Kurikulum 2013 adalah rumusan tentang standar kompetensi lulusan yang dirancang untuk mengembangkan kompetensi sikap, pengetahuan, dan keterampilan secara terpadu. Setelah SKL elemen kedua yang disempurnakan adalah standar isi yang berisi rumusan tentang kerangka dasar dan struktur kurikulum yang di dalamnya memuat kompetensi inti dan kompetensi dasar untuk mencapai SKL. Elemen ketiga yang disempurnakan dalam Kurikulum 2013 adalah cara yang digunakan untuk membelajarkan peserta didik untuk menguasai SKL dan standar isi yang dituangkan dalam standar proses.

Penelitian yang mengambil objek sasaran pembelajaran bahasa Indonesia sudah banyak dilakukan, namun penelitian pembelajaran bahasa Indonesia yang berbasis teks belum banyak dilakukan. Hal itu dapat dimaklumi, karena model pembelajaran bahasa Indonesia dengan titik masuk berupa pembelajaran unsur bahasa yang memiliki struktur berpikir lengkap, yaitu teks itu sendiri, baru berjalan dengan hadirnya Kurikulum 2013.

Tujuan akhir dari pembelajaran teks ialah menjadikan pembelajar memahami serta mampu menggunakan teks sesuai dengan tujuan sosial teks-teks yang dipelajarinya. Untuk mencapai kompetensi itu, mengingat bahwa teks merupakan satuan bahasa terkecil dengan struktur berfikir yang lengkap, maka pembelajaran teks haruslah dilaksanakan dengan tahapan yang kompleks.

Pendekatan saintifik dalam pembelajaran bahasa dimaksudkan sebagai cara pandang dalam melihat substansi dasar yang menjadi materi pembelajaran. Teks sebagai unit kebahasaan yang menjadi materi dasar pembelajaran bahasa dipandang sebagai sesuatu yang sistematis, terkontrol, empiris, dan kritis sebagaimana ciri-ciri kegiatan saintifik dalam ilmu pengetahuan (Kirlinger dalam Mahsun,2018). Selanjutnya, dalam kurikulum 2013 ada beberapa metode pembelajaran yang 
dianjurkan untuk diterapkan dalam kegiatan belajar mengajar diantaranya adalah model pembelajaran berbasis proyek dan berbasis masalah.

\section{METODE PENELITIAN}

Data dalam penelitian ini bersumber pada guru bahasa Indonesia kelas $\mathrm{X}$ dan dokumen. Adapun dokumen yang digunakan dalam penelitian ini terdiri dari dokumen RPP yang dimiliki oleh guru Bahasa Indonesia kelas X di Sekolah Menengah Atas Negeri dan Swasta yang terdapat di kota Mataram. Pada penelitian ini RPP yang akan dianalisis ada enam RPP bahasa Indonesia materi teks anekdot.

Melalui data berupa RPP, peneliti akan menganalisis kemampuan guru mendesain rencana pelaksanaan pembelajaran (RPP) dengan berfokus pada kemampuan mengembangkan indikator dari kompetensi dasar, kemampuan menentukan materi pembelajaran sesuai dengan indikator, kemampuan untuk menentukan metode pembelajaran, dan kemampuan menetapkan bentuk evaluasi capaian hasil pembelajaran.

Data dalam penelitian ini dianalisis menggunakan metode kualitatif. Miles dan Huberman (dalam Sugiyono, 2016:246), mengemukakan bahwa aktivitas dalam analisis data kualitatif dilakukan secara interaktif dan berlangsung secara terus menerus sampai tuntas. Menganalisis data dilakukan dalam tiga langkah yaitu reduksi data (data reduction), penyajian data (data display), dan verifikasi (conclusion drawing).

\section{HASIL DAN PEMBAHASAN}

Penelitian ini memperoleh beberapa hasil penelitian berupa data penelitian. Data tersebut dideskripsikan sesuai dengan fakta dan kajian teori yang terkait. Pemaparan tersebut diuraikan dalam pembahasan.

\section{Kemampuan Mengembangkan Indikator Pembelajaran Teks Anekdot}

Hasil kemampuan guru dalam menyusun RPP diperoleh menggunakan instrument kesesuaian komponen RPP.
Hasil penelitian semua RPP guru Bahasa Indonesia kelas $\mathrm{X}$ sudah mencantumkan kompetensi dasar dan indikator pencapaian kompetensi. Namun dalam RPP tidak semua dari aspek penilaian dijabarkan dengan baik. Ditemukan rumusan indikator yang penjabarannya masih kurang dan tidak sesuai sehingga tidak dapat digunakan untuk mengukur ketercapaian kompetensi dasar (KD). RPP yang rumusan indikator penjabarannya masih kurang dan tidak sesuai sehingga tidak dapat digunakan untuk mengukur ketercapaian kompetensi dasar (KD) yaitu pada RPP guru SMA Muhamadiyah dan MA Hidayatullah. Adapun letak ketidaksesuaiannya dua RPP tersebut sama-sama yaitu pada indicator 4.1.1 menganalisis struktur, 4.1.2 mengidentifikasi, 4.1.3 menganalisis gaya penceritaan, 4.1.5 menyimpulkan hasil analisis, dan 4.1.6 Menceritakan kembali isi teks anekdot. Kemudian, untuk empat RPP yang rumusan indicator banyak memperoleh kategori sudah sesuai yaitu RPP guru SMAN 8, MAN 1, SMAN 4, dan SMK Muhamadiyah. Adapun letak ketidaksesuaian empat RPP tersebut rata-rata terdapat pada indicator 4.1.3 menganalisis gaya penceritaan, 4.1.6 Menceritakan kembali isi teks anekdot, dan indicator 4.1.7 menyusun teks anekdot berdasarkan kejadian.

\section{Kemampuan Menentukan Materi Pembelajaran Teks}

Hasil penelitian rumusan materi pembelajaran dalam enam RPP belum semua sesuai dengan ketentuan. Pada RPP yang telah disusun oleh guru bahasa Indonesia dari enam sekolah ditemukan rumusan materi sudah sesuai dengan keempat rumusan Kompetensi Dasar (KD) dan mencantumkan uraiannya pada setiap pertemuan pembelajaran walaupun dalam rumusannya belum tersusun dengan baik dan masih terdapat kekurangan. Hal tersebut dapat diketahui dari materi yang diinginkan dalam Kompetensi dasar sudah tertera dalam rumusan materi yang ditulis oleh guru.

Pada rumusan materi pembelajaran yang telah disusun oleh guru bahasa Indonesia kelas X Kota Mataram dapat diketahui bahwa rumusan materi pembelajaran telah disusun berdasarkan muatan fakta, konsep, prinsip, dan prosedur yang relevan berdasarkan ketetapan Permendikbud 
Nomor 22 tahun 2016. Adapun untuk Rumusan materi pokok-pokok isi anekdot sudah tercantum dan sesuai dengan tuntutan dari KD. Pada rumusan KD tuntutan yang dipaparkan untuk teks anekdot adalah Isi anekdot, Anekdot dengan humor, kritik dalam teks anekdot, makna tersirat dalam teks anekdot, struktur, gaya penceritaan, dan bentuk kebahasaan teks anekdot.

\section{Kemampuan Menentukan Metode Pembelajaran}

Metode yang direkomendasikan untuk diterapkan dalam kegiatan belajar mengajar dalam kurikulum 2013 adalah metode saintifik/ilmiah yang diperkaya dengan pembelajaran discovery, pembelajaran berbasis masalah, pembelajaran berbasis proyek, pembelajaraan kooperatif, pembelajaran komunikatif, dan pembelajaran kontekstual. Metode-metode tersebut dapat dipilih satu atau dua metode yang selaras dengan KD yang hendak dikompetenkan. Metode yang dirancang dalam RPP adalah metode yang dinyatakan secara eksplisit atau disimpulkan dari kegiatan pembelajaran. Metode yang dipilih harus tercermin pada langkah-langkah kegiatan pembelajaran yang dirancang.

Metode pembelajaran, digunakan oleh pendidik untuk mewujudkan suasana belajar dan proses pembelajaran agar peserta didik mencapai Kompetensi Dasar yang disesuaikan dengan karakteristik peserta didik dan KD yang akan dicapai. Hasil penelitian rumusan metode pembelajaran pada RPP guru SMAN 8 Mataram, SMA Muhammadiyah, SMKN 4 Mataram, dan MAN 1 Mataram sudah sesuai dengan ketentuan kurikulum 2013 seperti dalam metode pembelajaran terdapat pendekatan, model pembelajaran dan metode pembelajaran. Sementara itu, pada Rencana pelaksanaan pembelajran yang telah disusun oleh guru bahasa Indonesia pada jenjang SMA Muhammadiyah Mataram menggunakan metode yang kurang tepat dan SMK
Muhammadiyah juga masih kurang sehingga bisa dikatakan belum mampu dalam menetapkan metode pembelajaran.

\section{Kemampuan Menentukan Bentuk Evaluasi}

Penilaian aspek pengetahuan dilakukan melalui tes tertulis, tes lisan, dan penugasan sesuai dengan kompetensi yang dinilai. Penilaian keterampilan dilakukan melalui praktik, produk, proyek, portofolio, dan/atau teknik lain sesuai dengan kompetensi yang dinilai. Setelah melakukan pemeriksaan dokumen Rencana Pelaksanaan Pembelajaran (RPP), ditemukan data bahwa untuk rumusan evaluasi atau penilaian yang disusun oleh enam guru jenjang sekolah SMAN 8 Mataram, SMKN 4 Mataram, MAN 1 Mataram, SMA Muhammadiyah, SMK Muhammadiyah dan MA Hidayatullah Kota Mataram tersebut sudah sesuai. Hal ini terbukti dengan pemerolehan keseluruhan berkategori sudah sesuai. Pada Rencana Pelaksanaan Pembelajaran (RPP) sudah tercantum rumusan komponen penilaian, dilengkapi butir instrument untuk penilaian kompetensi sikap, penilaian kompetensi pengetahuan dan penilaian kompetensi keterampilan.

Komponen dalam RPP yang akan dianalisis adalah aspek penilaian pembelajaran teks anekdot berdasarkan berdasakan permendikbud nomor 23 tahun 2016 pasal 9 tentang mekanisme penilaian hasil belajar oleh pendidik. Ditetapkan bahwa penilaian aspek sikap dilakukan melalui observasi/pengamatan dan teknik penilaian lain yang relevan, dan pelaporannya menjadi tanggungjawab wali kelas atau guru kelas; penilaian aspek pengetahuan dilakukan melalui tes tertulis, tes lisan, dan penugasan sesuai dengan kompetensi yang dinilai; dan penilaian keterampilan dilakukan melalui praktik, produk, proyek, portofolio, dan/atau teknik lain sesuai dengan kompetensi yang dinilai. Sesuai focus rumusan masalah, yang akan dianalisis hanya berkaitan dengan aspek pengetahuan dan keterampilan.

\section{KESIMPULAN}

Kesimpulan berisi rangkuman singkat atas hasil penelitian dan pembahasan. [Times New Roman, 12, normal]. Berdasarkan hasil penelitian dan pembahasan tentang kemampuan guru bahasa Indonesia kelas X Kota Mataram 
dalam menyusun RPP berbasis Kurikulum 2013, maka diperoleh kesimpulan bahwa kemampuan guru bisa dikatakan kurang mampu. Apabila dilihat dari kelengkapan komponen yang ada di dalam RPP yang disusun guru, bisa dikatakan sudah sesuai. Namun masih ada terdapat beberapa kekeliruan seperti komponen dari RPP yang tidak dicantumkan secara lengkap. Dalam hal kemampuan guru dalam merumuskan RPP bisa dikatakan kurang mampu. Hal tersebut dapat dilihat dari hasil analisis yang telah dilakukan.

Rumusan indikator pada RPP guru untuk enam sekolah sudah mencantumkan kompetensi dasar dan indikator pencapaian kompetensi. Namun dalam RPP tidak semua dari aspek penilaian dijabarkan dengan baik. Ditemukan dua RPP yang rumusan indikator penjabarannya masih kurang dan tidak sesuai sehingga tidak dapat digunakan untuk mengukur ketercapaian kompetensi dasar (KD) yaitu pada RPP guru SMA Muhamadiyah dan MA Hidayatullah. Ditemukan tiga RPP yang rumusan materi penjabarannya masih kurang berdasarkan muatan fakta, konsep, prinsip, dan prosedur yang relevan sesuai ketetapan Permendikbud Nomor 22 tahun 2016, yaitu pada RPP guru SMA Muhamadiyah, SMK Muhamadiyah, dan MA Hidayatullah. Kemudian untuk rumusan metode pembelajaran terdapat dua RPP guru yang kurang lengkap yaitu RPP guru SMA Muhamadiyah dan SMK Muhamadiyah.

Rumusan evaluasi atau penilaian pembelajaran teks anekdot yang disusun oleh enam guru sudah sesuai berdasarkan permendikbud nomor 23 tahun 2016 pasal 9 tentang mekanisme penilaian hasil belajar oleh pendidik. Hal ini terbukti dengan pemerolehan keseluruhan berkategori sudah sesuai. Pada Rencana Pelaksanaan Pembelajaran (RPP) sudah tercantum rumusan komponen penilaian, dilengkapi butir instrument untuk penilaian kompetensi pengetahuan dan penilaian kompetensi keterampilan. Jadi bisa dikatakan, guru bahasa Indonesia kelas $\mathrm{X}$ Kota Mataram, jika dilihat dari kelengkapan komponen bisa dikatakan kurang mampu karena dalam rumusan komponen tersebut masih banyak yang belum tersusun secara sempurna. Komponen RPP yang masih banyak ditemukan kekeliruan dalam proses penyusunannya adalah indikator.

\section{SARAN}

Dari hasil penelitian dan kesimpulan, ada beberapa hal yang disarankan supaya guru bahasa Indonesia Kota Mataram dapat menyusun RPP sesuai dengan standar Kurikulum 2013. Saran tersebut antara lain:

1. Pelatihan untuk guru dalam penerapan Kurikulum 2013 hendaknya merata.

2. Saat seorang guru menyadari bekal tentang Kurikulum 2013 belum cukup, sebaiknya guru tersebut terus berupaya meningkatkan pemahamannya tentang Kurikulum 2013 dengan cara mengikuti seminar, workshop, dan lainnya.

3. Guru harus berupaya untuk meningkatkan pemahaman terutama mengenai penyusunan perencanaan pelaksanaan pembelajaran.

\section{DAFTAR PUSTAKA}

Asropah, dkk. 2017. Kemampuan Menyusun RPP Kurikulum 2013 Revisi2017 Guru Bahasa Jawa SMA Kota Semarang. Media Penelitian Pendidikan. Vol. 11. No 2. 2017.

Bukran. 2013. Problematika Pembelajaran Bahasa Indonesia Kurikulum 2013 Guru SMA Kelas X Di Kabupaten Lombok Utara. Tesis. Universitas mataram.

Bayangkari. 2014. Perbandingan Kurikulum KTSP dengan Kurikulum 2013 Mata Pelajaran Bahasa dan Sastra Indonesia di SMK. Tesis. Universitas Mataram.

Kemdikbud, 2016. Peraturan Menteri Pendidikan dan Kebudayaan RI Nomor 22 Tahun $2016 \quad$ Tentang Standar Proses Pendidikan Dasar dan Menengah. Jakarta, Kemdikbud.

Kemdikbud, 2018. Peraturan Menteri

Pendidikan dan Kebudayaan RI Nomor 37 Tahun 2018 Tentang Kompetensi Inti 
Jurnal Ilmu Sosial dan Pendidikan

http://ejournal.mandalanursa.org/index.php/JISIP/index

Terakreditasi Peringkat 5 (No. SK: 85/M/KPT/2020)
Vol. 4. No. 3 Juli 2020

p-ISSN: 2598-9944 e-ISSN: 2656-6753 dan Kompetensi Dasar Pelajaran

Pada Kurikulum 2013 Pada

Pendidikan Dasar dan Menengah. Jakarta

Lestari, Aa Nunu Aste. 2019. Kemampuan Guru Melaksanakan Pembelajaran Bahasa Indonesia Berbasis Kurikulum 2013 di SMPN 1 Pujut. Tesis. Program Pascasarjana Pendidikan Bahasa Indonesia. Universitas Mataram.

Lestari, Meylinda Dwi. 2015. Analisis

Kemampuan Guru Biologi SMA di Kota Semarang dalam Membuat Rencana Pelaksanaan Pembelajaran Berdasarkan Kurikulum 2013. Skripsi. Universitas Negeri Semarang. https://lib.unnes.ac.id/28118/1/440 1410082.pdf

Mahsun. 2018. Pembelajaran Bahasa Indonesia Berbasis Teks. Depok : PT Rajawali. Pers Mahsun. 2017. Metode penelitian bahasa. Depok : PT Rajawali Pers.

Mahsun, Dkk. 2017. "Laporan Penelitian

Kemampuan Memproduksi Teks Genre Cerita Melalui Metode Saintifik Siswa Kelas XI SMA di Kota Mataram". FKIP. Program Pascasarjana Pendidikan Bahasa Indonesia: LPMP Universitas Mataram.

Mahayoningrum,Prita. 2014. Analisis RPP Bahasa Indonesia Aspek Keterampilan Menulis Kelas XI SMAN 2 Jember Tahun Ajaran 2012/2013. Universitas Jember. http://repository.unej.ac.id/handle/1 23456789/61719

Mei Anggriani Aruan dkk. 2017. Analisis

Rencana

Pelaksanaan

Pembelajaran Guru Bahasa Indonesia SMAN 7 Medan Tahun Pembelajaran 2016/201. Basastra. Vol 6.No 2. 2017.https://jurnal.unimed.ac.id/20 12/index.php/basastra/article/view/ 6379/5593
Muhammad. 2014. Metode Penelitian Bahasa. Yogyakarta. Ar-Ruzz Media.

Rusydiyah, Evi Fatimatur. 2017. Desain Pembelajaran Inovatif : Dari Teori ke Praktik. Jakarta : Rajawali Pers

Sugiono. 2016. Metode Penelitian. Bandung: Alfabeta.

Susdiana, Baiq Emilia. 2019. Implementasi Kurikulum 2013 dalam Pembelajaran Bahasa Indonesia di SMAN 1 Praya Barat di Kabupaten Lombok Tengah. Tesis. Program Pascasarjana Pendidikan Bahasa Indonesia. Universitas Mataram.

Setyawanto, Agung. 2012. Rencana

Pelaksanaan Pembelajaran Guru Bahasa Indonesia Tingkat SMP di Kota Malang. Universitas Negeri Malang. https://jurnalonline.um.ac.id/data/artikel/ artikelB75014B49ADF96FF1A3C8AA0 2E089935.pdf

Saputra, Widadi Ambar. 2011. Pemetaan

Kompetensi Guru SMP Islam Terpadu Ihsanul Fikri Sebagai Sekolah Standar Nasional. Tesis. Pascasarjana Ilmu Administrasi.UniversitasIndonesia.http:// lib.ui.ac.id/file?file=digital/20267032T28 929Pemetaan\%20kompetensi.pdf

Suryani, Janie Irma. 2017. Pengembangan Rencana Pelaksanaan Pembelajaran Berbasis Bermain Peran Untuk Pemahaman Nilai-Nilai Demokrasi Pada Siswa Kelas IV Sekolah Dasar. Pascasarjana Universitas Lampung. http://digilib.unila.ac.id/29127/

Utami, Wiwik Surya.2018. Kemampuan Guru Bahasa Indonesia SMPN

1 Sumbawa Dalam Mendesain dan Menerapkan Rencana Pembelajaran Teks Hasil Observasi. Tesis. Pascasarjana Unram. https://jurnal.unimed.ac.id/2012/index.ph p/basastra/article/download/12973/11050

Widarto. 2014. Penyusunan RPP Pada

Kurikulum 2013. Lembaga Pengembangan dan Penjaminan Mutu Pendidikan. Universitas Negeri Yogyakarta.http://staff.uny.ac.id/sites/def ault/files/pengabdian/dr-widarto 
Jurnal Ilmu Sosial dan Pendidikan

http://ejournal.mandalanursa.org/index.php/JISIP/index

Terakreditasi Peringkat 5 (No. SK: 85/M/KPT/2020)
Vol. 4. No. 3 Juli 2020

p-ISSN: 2598-9944 e-ISSN: 2656-6753

mpd/16rambu-rambu-penyusunan-

rpp.pdf 